\title{
喉頭腺様囊胞癌で判明した四重癌例
}

\author{
村川 哲也・小坂 道也・森聡人
}

\section{A Case of Quadruple Cancers with Adenoid Cystic Carcinoma of Larynx}

\author{
Tetsuya Murakawa, Michiya Kosaka and Yoshito Mori \\ (Kagawa Rosai Hospital)
}

\begin{abstract}
Malignant tumors arising from laryngeal gland cells are extremely rare. No more than $1 \%$ of the epithelial malignancies of the larynx are nonsquamous carcinomas. Moreover, adenoid cystic carcinomas make up fewer than $0.25 \%$ of all malignancies of the larynx. In the Japanese literature, only 28 cases have been reported. We have encountered a case of laryngeal (supraglottic) adenoid cystic carcinoma.

A 68-year-old woman complained of hoarseness and slight dyspnea of six months' duration. We suspected a thyroid carcinoma and laryngeal tumor. We performed fine needle aspiration for the thyroid mass, and findings suggested papillary carcinoma. Laryngoscopic examination revealed a smooth mass involving the right false vocal cord and epiglottis. The pathology report indicated adenoid cystic carcinoma. The patient underwent total laryngectomy, subtotal thyroidectomy, right neck dissection, and reconstruction with LDMC. We examined the resected specimens histologically by whole organ serial sectioning and discussed the evaluation, treatment, clinical course and prognosis of adenoid cystic carcinoma of the larynx. The overall 10-year survival rate is worse than the overall 5-year survival rate. Therefore, we must observe cases of adenoid cystic carcinoma for over 10 years.
\end{abstract}

Key words : adenoid cystic carcinoma, laryngeal carcinoma, nonsquamous carcinoma

\section{はじめに}

腺様襄胞癌は大小唾夜腺に好発するが，喉頭に発生す る悪性腫瘍のほとんどは扁平上皮癌であり, 喉頭の腺様 囊胞癌の発生率は喉頭の全悪性腫瘍中の $0.25 \%$ 以下と報 告され1)，文献的にもまれである。われわれが渉猟しえ た範囲でも，本邦では28例の報告があるに過ぎない，

今回, われわれは喉頭の腺様㖣胞癌で判明した四重癌 の 1 症例を経験したので, 若干の文献的考察を加えて報 告する.

\section{症例}

患者 : 68歳, 女性.

主訴 : 嗄声, 軽度呼吸困難.
既往歷 : 1979年に左乳癌にて左乳房切除術を施行した。

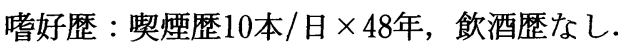

家族歴 : 特記事項なし。

現病歴 : 1998年 6 月頃より, 嗄声が出現し, 走ると呼 吸困難を軽度認めていた．嗄声が持続するため，11月 25 日, 近医耳鼻咽喉科を受診したところ, 甲状腺癌扤よび 喉頭の腫瘍性病変が疑われたため，12月17日，当科を紹 介され受診した。前医での甲状腺の穿刺吸引細胞診の結 果は乳頭癌であった. 1999年 1 月 5 日，精査加療目的で 当科に入院した.

初診時所見：喉頭ファイバー下に，披裂喉頭蓋ヒダを 中心に舌根部から右喉頭腔に向から隆起性病変を認めた が，右声帯の動きは観察できなかった．頸部リンパ節は 
触知しなかった。

初診時検査所見：Free T4 $1.3 \mathrm{ng} / \mathrm{ml}$ (基準值0.97 1.79）, TSH $0.51 \mu \mathrm{IU} / \mathrm{ml}$ (基準值0.6〜 5.1), その他, 異常所見なし。

画像所見：頸部 MRI（図 1 ); 喉頭の右側飞 $2 \times 3 \mathrm{~cm}$ 程度の楕円形の腫瘍を認め, 喉頭は左側へ強く圧排され ていた。周困との境界は比較的明瞭で, T2 強調で内部 信号強度が不均一であった。.甲状腺には 2 力所占拠性病 変があり，T2 強調で高信号を呈していた．

胸部 CT (図 2 ); 縱隔にリン八゚節腫大や胸水を認めな かった。左肺下葉, 横隔膜直上に $2 \times 2.5 \mathrm{~cm}$ の結節状 陰影を認めた。 辺縁に凹凸があり，胸膜の陥凹を伴って いた。

Ga-シンチ；喉頭の腫瘤に一致して高集積を認めたが， 甲状腺には異常集積を認めなかった. 左肺門部にも集積 を認めた。

経過 : 入院時, 軽度呼吸困難を訴兄ていたため, 1999 年 1 月 6 日, 喉頭直達鏡下生検と気管切開術を施行した。 腫瘍は右仮声带の粘膜下に存在し, 粘膜に切開を加党, 粘膜下より生検した。生検結果は腺様囊胞癌であった。 また, 肺病変に関しては気管支ファイバーで生検を試

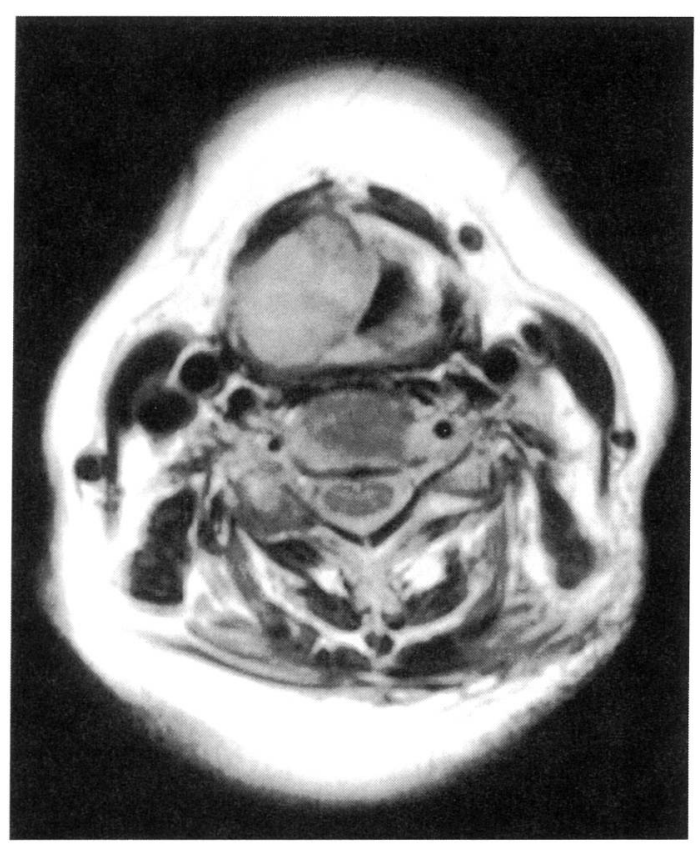

図 1 頸部 MRI 写真

喉頭の右側に $2 \times 3 \mathrm{~cm}$ 程度の楕円形の腫瘍を認め, 喉頭 は左側へ強く圧排されていた。

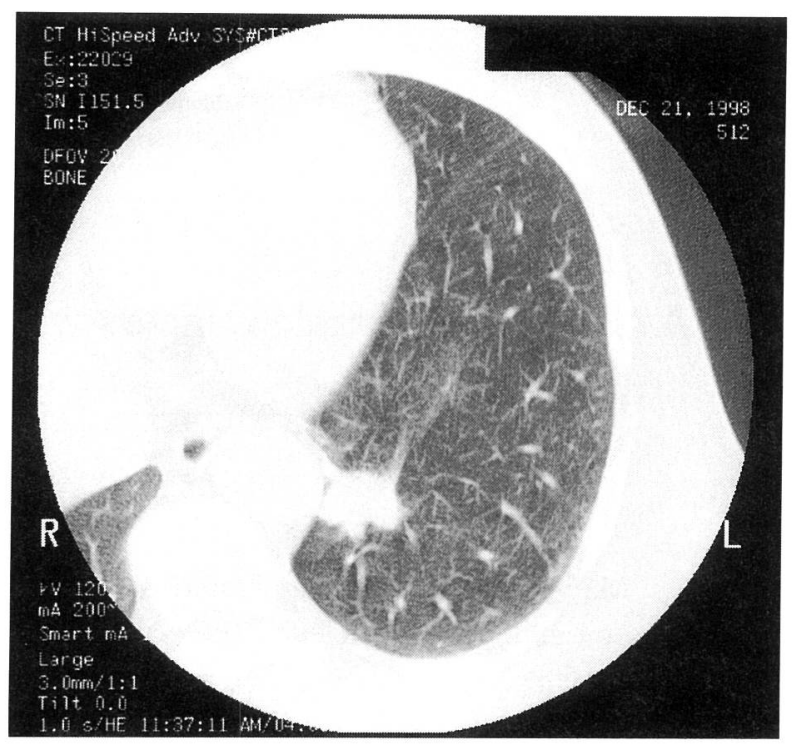

図 2 胸部 $\mathrm{CT}$ 写真

左肺下葉, 横隔膜直上飞 $2 \times 2.5 \mathrm{~cm}$ の 結節状陰影を認 めた。

みるも, 病変が小さく、十分な診断ができなかったが, CT 所見では原発性の肺癌が強く疑われ，遠隔転移は否 定的であった.

喉頭の生検結果と甲状腺の穿刺吸引細胞診の結果, そ して画像診断より, 喉頭声門上型腺様囊胞癌 (T4N0M0) と甲状腺乳頭癌の重複癌と考克, 2 月 2 日喉頭全摘術, 甲状腺亜全摘術, 右機能的頸部郭清術, 右下咽頭拈よび 舌根の部分切除術，広背筋有茎皮并を用いた再建術を施 行した.

術中所見: 気管切開部を通るようにU字切開を加兄, 右機能的頸部郭清術を施行した(図 3 ). 気管切開部周囲 は痗痕組織が多く, 剥離が困難であった。甲状腺は左葉 の上極を残し，残りの部分を気管壁に付けたま覀全摘 し，甲状腺周团のレベル $\mathrm{I} \sim \mathbb{N}$ のリンパ節郭清を行った。 次に, 喉頭の腫瘍に対しては, 喉頭とともに舌根の一部 と下咽頭後壁叔よび右梨状陥凹の粘膜を合併切除し，欠 損した粘膜の部位 $10 \times 6 \mathrm{~cm}$ の右広背筋有茎皮升用 いて再建した.

摘出標本（図 4)：喉頭の腫瘍は披裂喉頭蓋ヒダから右 披裂部，右仮声帯にかけての粘膜下に存在していた。視 診上, 両声帯は正常であった。

病理組織標本：喉頭癌の腫瘍細胞は, 小型楕円形で異 型性軽度の細胞が囊胞状, 索状に増殖し, 大小種々の胞 


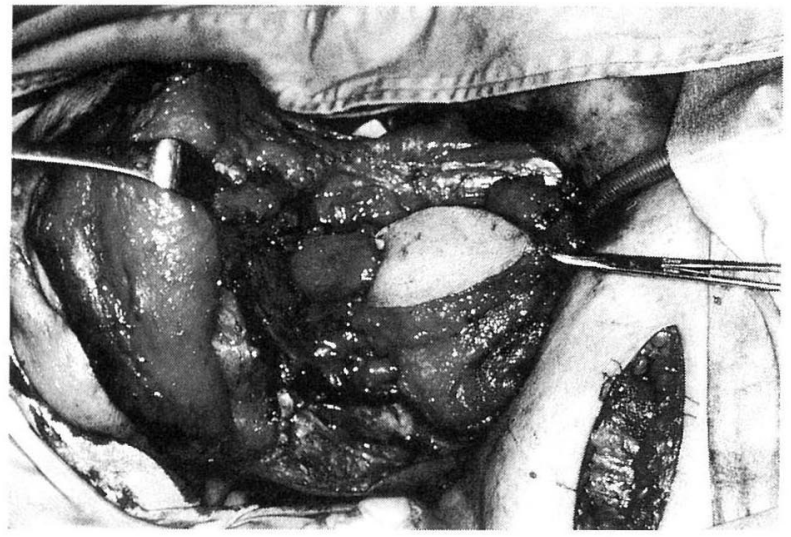

図 3 術中写真

欠損した粘膜の部位を $10 \times 6 \mathrm{~cm}$ の右広背笳有茎皮弁を 用いて再建した。

巣を形成するいわゆる cribriform 型を呈していた。個 個の腫瘍細胞は腺上皮細胞と筋上皮細胞が混在する biphasic 型が文られた．前者は比較的豊富な細胞質と淡 明な核を有し，主に腺管を形成していた。後者は狭小な
細胞質と濃縮核を有し，やや紡錘形で偽囊胞壁と胞巣周 囲に配列していた(図 5 ).

甲状腺は峡部にの久乳頭癌を認めた。被膜をもたず， 乳頭状構造を示す濾胞上皮由来の高分化型の腫瘍であっ た。核内細胞質封入体やスリガラス状の核質を認め，直 径 $10 \mathrm{~mm}$ の最大径を示す病変であった(図 6 ).

術後経過：3月 2 日よりチラージン $\mathrm{S}^{\circledR を} 2 \mathrm{~T} /$ 日, UFT 顆粒 $1.5 \mathrm{~g} /$ 日を内服開始した。経過良好で 3 月 10 日にはいったん退院した，午の後，当院内科にて肺病変 の精査を行い, CT ガイド下に生検施行した結果, V群 を認めたため，6月 7 日に当院外科にて，左肺下葉切除 術を施行した。腫瘍は $\mathrm{S}^{10}$ に位置し，腫瘍径は $2.8 \times 2.5$ $\times 1.9 \mathrm{~cm}$ で, T1N0M0, Ia 期の診断であった. 病理組 織標本では, 肺胞壁を置換性に核異型を示す腺癌細胞の 増殖を認め, 高分化型腺癌であった(図 7 ).

\section{考察}

1. 本邦報告例の検討 : 腺様囊胞癌の喉頭での発生は きわめてまれであり，本邦での報告は自験例を含め，29
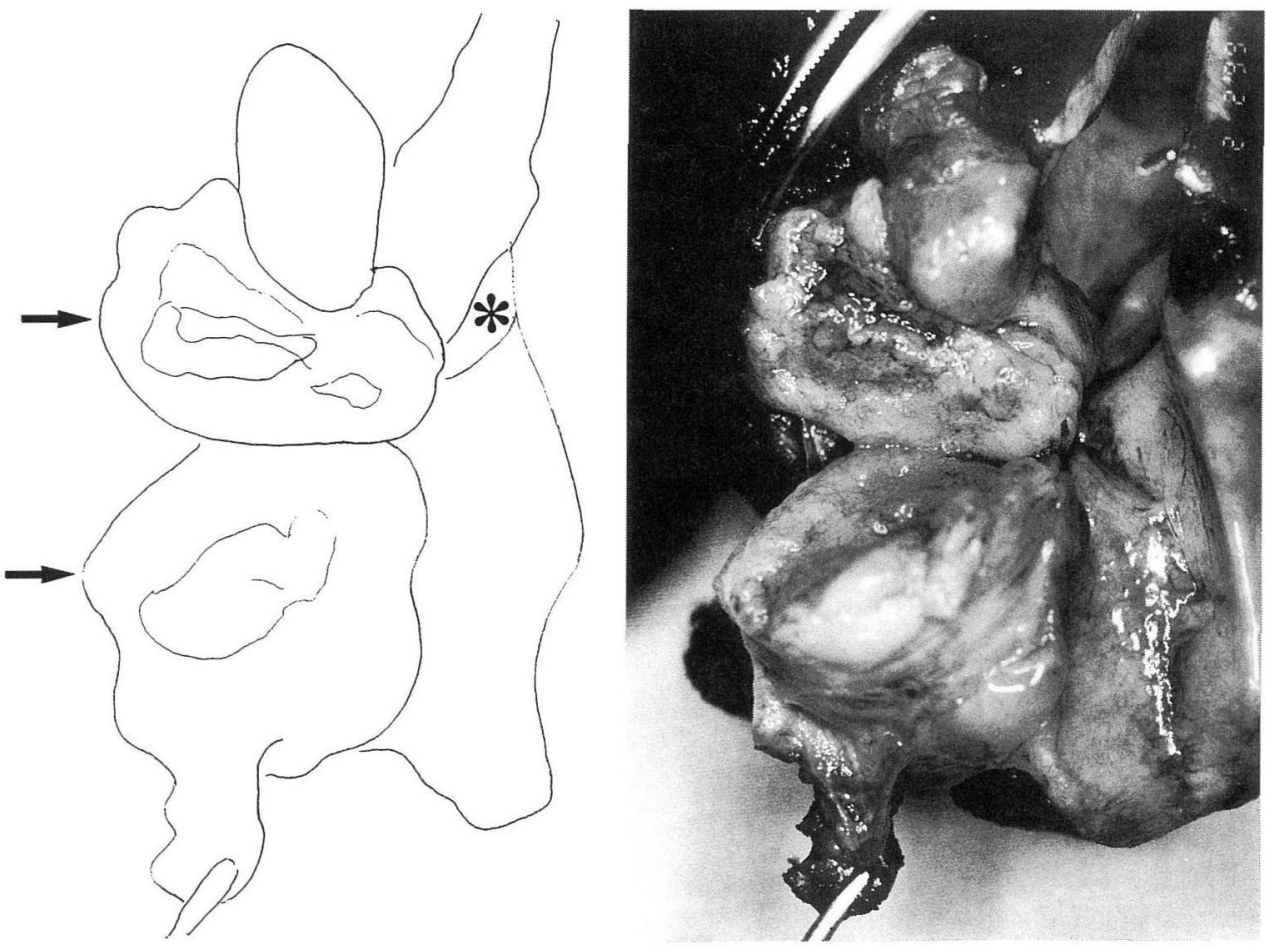

図 4 摘出標本

喉頭の腫瘍(矢印)は披裂喉頭蓋ヒダから右披裂部，右仮声帯にかけての粘膜下に存在して いた. 左声帯 $(*)$ 


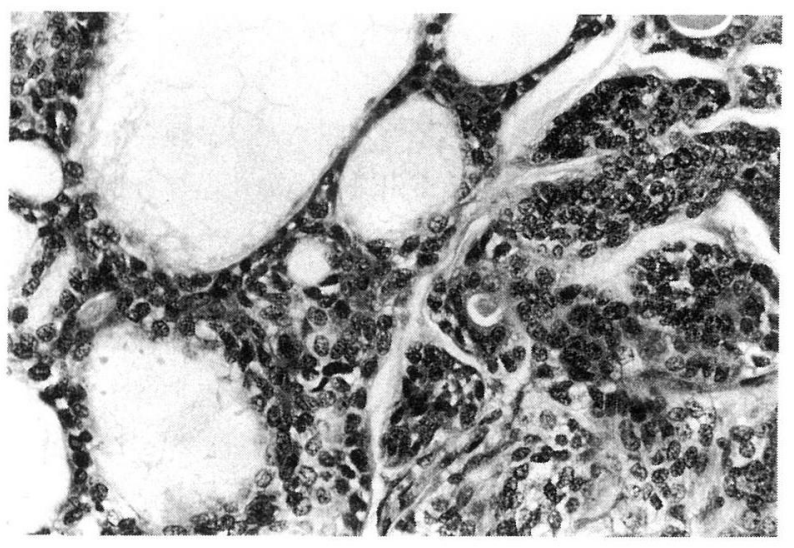

図 5 喉頭癌病理組織標本の強払大像 (HE 染色, 100倍) 小型楕円形で異型性軽度の細胞が囊胞状, 索状に増殖し, cribriform 型を呈していた.

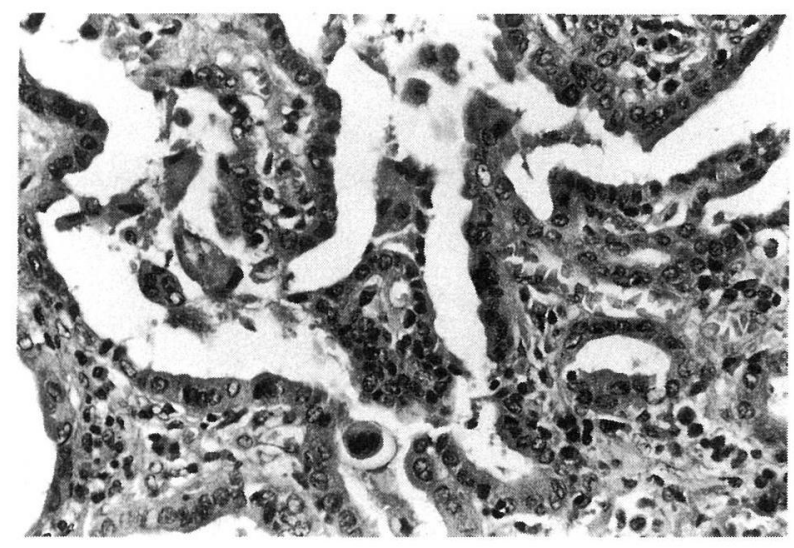

図 6 甲状腺癌病理組織標本の強払大像 (HE 染色, 100倍) 被膜をもたず，乳頭状構造を示し，核内細胞質封入体や スリガラス状の核質を認めた。

例に過ぎない(表 1 )。これまで文献的に報告された国内 例28例2) 26) と自験例について比較，検討した。

喉頭扁平上皮癌の発生は男性が 9 割以上を占めている が，これは契煙，食事，口腔内の不衛生などによる污染 や刺激，すなわち男性的気質が発生に関与するとされて いる。それに対し，腺様囊胞癌の男女比は $14: 15$ とほ 添同数であったことより, 腺様囊胞癌の発癌因子として 男性的気質よりも遺伝，体質など他の因子の関与が示唆 された. TNM 分類が判明した 24 症例のらら, 13 例(54.2 \%)が進行癌であり，㾫平上皮癌と比較して進行癌が多 いといら印象がある(表 2 )。発生部位からみると, 喉頭 腺の多く分布する声門上の頻度が最も高く, 喉頭腺の少

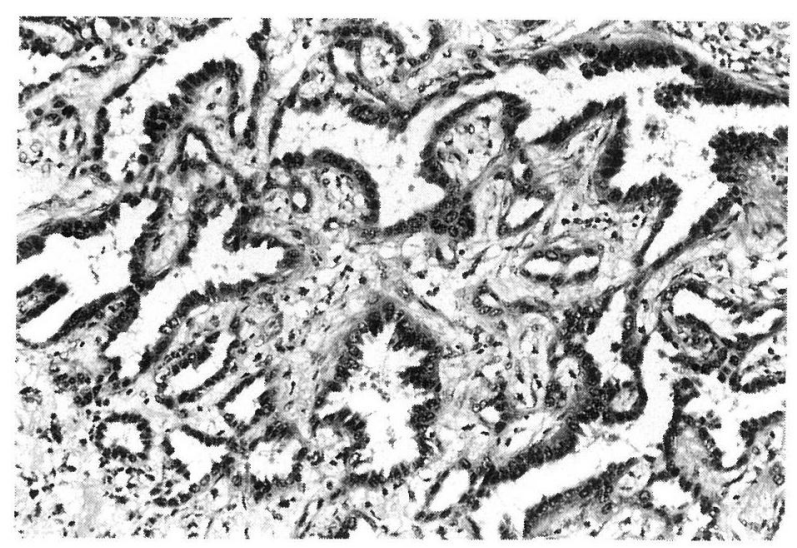

図 7 肺癌病理組織標本の強拡大像 (HE 染色, 100倍) 肺胞壁を置換性に核異型を示す腺癌細胞の増殖を認め た。

ない声帯には 1 例もなかった(表 3 ). 主訴は嗄声が14例 と最も多かったが，これは声門上部の病変が進行し声帯 部にまで及んでいる症例が多いのが原因だと考えた（表 4 ). 自験例では喉頭の腫瘍は披裂喉頭蓋ヒダから右披 裂部, 右仮声帯にかけての粘膜下に存在して物り, それ が嗄声の原因ではないかと考光た。咽喉頭異常感が 11 例 を占めたのも声門上部に病変が多いことが影響を及ぼし ているのではないかと考光た。

2 . 画像診断 : 頸部 MRI 上, 喉頭の腫瘍性病変を認 めたが，甲状腺癌のリンパ節転移としては位置が高く, 考皃にくかった。また，境界が比較的明膫であり，当初 は腺様囊胞癌以外にも粘表皮癌や良性腫瘍を疑った。

3. 治療法：化学療法と放射線療法を併用して子根治 は難しく, 手術療法による病变の根治切除が第一選択と され，本邦に特いては29例中26例に手術療法が施行され ている(表 5 ).

術式は, 喉頭全摘術, 喉頭部分切除術が主流であるが, レーザーによる腫瘍焼灼術も報告されている10). 自験例 では当初, 搌頭部分切除術の適応を検討したが, 腫瘍径 が大きく, かつ悪性であったこと, また, 安全域を2 $\mathrm{cm}$ 以上付けること考慮した結果, 部分切除術の適応 ではないと判断した。 また，部分切除術だと誤喂性肺炎 をきたす危険性があり，肺病变に対する手術への影響が 大きいと判断したことも喉頭全摘術を選択した理由の一 つであった。

Ferlito ら27)によると, 過去の非唾液腺由来の腺様囊 胞癌について検討し, 内臓転移(肺, 肝, 脳)をしばしば 
表 1 本邦の喉頭腺様囊胞癌症例

\begin{tabular}{|c|c|c|c|c|c|c|}
\hline 報告者, 年 & 年齢 & 性別 & 初 発 症 状 & 発 生 部 位 & TNM 分類 & 治 療 \\
\hline 竹田2) (1972) & 44 & 男 & 咽頭異常感 & 喉頭蓋 (supra) & T3N0M0* & $\mathrm{O}$ \\
\hline 豊田ら3)（1975） & 57 & 男 & 呼吸困難 & 不 明 & T4N0M0 & $\mathrm{O}+\mathrm{R}$ \\
\hline \multirow{2}{*}{ 佐藤ら ${ }^{4)}(1976)$} & 37 & 女 & 嚥下痛, 嚥下障害 & 披裂部 (supra) & T2N1M1* & $\mathrm{C}+\mathrm{R}$ \\
\hline & 68 & 男 & 喉頭異物感 & 右仮声帯 (supra) & T1N0M0 & $\mathrm{R}$ \\
\hline 小池ら5) (1978) & 70 & 女 & 嗄声, 呼吸困難 & 右声帯～声門下腔 (trans) & T2N0M0* & $\mathrm{O}$ \\
\hline 星谷ら6) (1978) & 82 & 男 & 嗄声, 喘鳴, 呼吸困難 & 左披裂喉頭蓋壁 (supra) & 記載なし & 加療せず \\
\hline 福島ら7) (1983) & 57 & 女 & 頸部腫瘤 & 喉頭蓋～左披裂部 (supra) & T2N1M0 & $\mathrm{O}+\mathrm{C}$ \\
\hline 佐藤ら ${ }^{8)}(1983)$ & 53 & 男 & 記載なし & 記載なし & 記載なし & $\mathrm{O}$ \\
\hline 牧ら9)（1984） & 51 & 女 & 咽喉頭異常感, 嗄声 & 声門下 (sub) & 記載なし & $\mathrm{O}+\mathrm{R}$ \\
\hline 石津ら ${ }^{10)}(1985)$ & 76 & 男 & 嗄声, 咽喉頭異常感 & 左仮声帯～前連合 (supra) & T2N0M0 & $\mathrm{L}$ \\
\hline 田辺ら ${ }^{11)}(1987)$ & 66 & 女 & 呼吸困難 & 声門下 (sub) & T3N0M0* & 0 \\
\hline 伊藤ら ${ }^{12)}(1988)$ & 72 & 男 & 記載なし & 記載なし & 記載なし & $\mathrm{O}$ \\
\hline 小山 ${ }^{13)}(1988)$ & 25 & 女 & 記載なし & 声門下 (sub) & 記載なし & $\mathrm{R}+\mathrm{O}$ \\
\hline 折館ら ${ }^{14)}(1989)$ & 83 & 男 & 嗄声, 咽喉頭異常感 & 右仮声帯～喉頭蓋 (supra) & T2N0M0* & $\mathrm{O}+\mathrm{R}$ \\
\hline 知念ら ${ }^{15)}(1989)$ & 35 & 男 & 嗄 声 & 声門下 (sub) & T4N0M0* & $\mathrm{L}$ \\
\hline 石毛ら ${ }^{16)}(1989)$ & 56 & 男 & 咽喉頭異常感 & 右披裂部～仮声帯 (supra) & $\mathrm{T} 2 \mathrm{~N} 1 \mathrm{M} 0^{*}$ & $\mathrm{O}$ \\
\hline 吉岡ら ${ }^{17)}(1989)$ & 48 & 男 & 嗄声, 讌下時異和感 & 左仮声帯 (supra) & T4N0M0 & $\mathrm{O}+\mathrm{R}$ \\
\hline 中島ら ${ }^{18)}(1991 ）$ & 56 & 女 & 嗄 声 & 両声帯～声門下 (trans) & T2N0M0* & $\mathrm{C}+\mathrm{O}$ \\
\hline 小川ら 19)（1993） & 56 & 女 & 嗄声, 咳, 血痰 & 左仮声帯～披裂部 (supra) & T3N0M0 & $\mathrm{O}$ \\
\hline 金田ら 20)（1993） & 44 & 女 & 嗄 声 & 右披裂部 (supra) & T3N0M0 & $\mathrm{O}$ \\
\hline 矢田ら ${ }^{21)}(1993)$ & 60 & 女 & 血 痰 & 声門下 (sub) & T1N0M0 & $\mathrm{O}$ \\
\hline 松永ら 22)（1993） & 61 & 女 & 咽喉頭異常感 & 喉頭蓋 (supra) & T2N0M0 & $\mathrm{O}$ \\
\hline \multirow{2}{*}{ 楠山²3)（1994） } & 74 & 男 & 咽喉頭異常感, 嗄声 & 右披裂部 (supra) & T1N0M0 & $\mathrm{O}$ \\
\hline & 59 & 女 & 咽喉頭異常感, 嗄声 & 声門下 (sub) & T1N0M0 & $\mathrm{O}$ \\
\hline 熊埜御堂ら ${ }^{24)}$ (1995) & 59 & 女 & 嗄声, 咽喉頭異常感 & 声門下 (sub) & T2N0M0 & $\mathrm{O}$ \\
\hline 植田 ${ }^{25)}(1998)$ & 68 & 男 & 嗄 声 & 披裂喉頭蓋壁 (supra) & T3N2bM0 & $\mathrm{O}$ \\
\hline \multirow{2}{*}{ 海沼26)（1999） } & 46 & 女 & 呼吸困難 & 声門下 (sub) & T3N0M0 & $\mathrm{O}+\mathrm{R}$ \\
\hline & 46 & 男 & 呼吸困難, 嗄声 & 声門下 (sub) & T4N0M0 & $\mathrm{O}+\mathrm{R}+\mathrm{C}$ \\
\hline 自験例(1999) & 64 & 女 & 嗄声, 呼吸困難 & 右仮声帯～披裂喉頭蓋壁 (supra) & T2N0M0 & $\mathrm{O}$ \\
\hline
\end{tabular}

* 報告の局所所見より推測したもの

$\mathrm{O}$ : 手術, $\mathrm{R}$ : 放射線療法, $\mathrm{C}$ : 化学療法, $\mathrm{L}:$ レーザ一焼灼

(supra) : supraglottic, (sub) : subglottic, (trans) : transglottic

認めるものの, リンパ節転移をきたしにくく，予防的頸 部郭清術は必要ないと報告されている。 しかし，自験例 では腫瘍が喉頭蓋に進展していることに加兄, 腫瘍径が 大きく, 声門上癌であったことや甲状腺癌との重複癌で
あることも考慮し, 予防的頸部郭清術を施行した. 左気 管傍リンパ節に乳頭癌の転移を認めたが，腺様囊胞癌の 転移は認めなかった。

化学療法は, シスプラチン, アドリアマイシン, ペプ 
表 $2 \mathrm{TNM}$ 分類

\begin{tabular}{c|cccc||r}
\hline \hline & $\mathrm{N} 0$ & $\mathrm{~N} 1$ & $\mathrm{~N} 2$ & $\mathrm{~N} 3$ & 計 \\
\hline $\mathrm{T} 1$ & 4 & 0 & 0 & 0 & 4 \\
$\mathrm{~T} 2$ & 7 & $3^{*}$ & 0 & 0 & 10 \\
$\mathrm{~T} 3$ & 5 & 0 & 1 & 0 & 6 \\
$\mathrm{~T} 4$ & 4 & 0 & 0 & 0 & 4 \\
\hline \hline 計 & 20 & 3 & 1 & 0 & 24
\end{tabular}

* M1 を 1 例含む

TNM 分類不明 5 例

表 3 発生部位

\begin{tabular}{lc}
\hline \hline 発生部位 & 症例数 \\
\hline supraglottic & 15 \\
glottic & 0 \\
subglottic & 9 \\
transglottic & 2 \\
unknown & 3 \\
\hline 計 & 29
\end{tabular}

表 4 主 訴

\begin{tabular}{cc}
\hline \hline 主 訴 & 症例数 \\
\hline 嗄声 & 14 \\
咽䐅頭異常感 & 11 \\
呼吸困難 & 4 \\
疼痛 & 2 \\
血痰 & 2 \\
㿥下障害 & 2 \\
頸部腫瘤 & 1 \\
咳 & 1 \\
喘鳴 & 1 \\
症状不明 & 3
\end{tabular}

レオマイシンなどによる多剤併用療法が有効であったと いう報告28)29）もあるが，無効との報告30131）もあり，ま だ統一した見解は得られていない。

放射線療法に対しては感受性が低いとされており，手 術拒否例や広範な進展のため術後に顕微鏡的残存が疑わ れる時の補助療法として用いられたといら報告がある24). 頭頸部領域では解剖学的な事情により安全域を確保で きない場合があり，そのような場合に化学療法や放射線 療法の併用が有用であると考える.

また，自験例では入院時に呼吸困難を訴えていたため，
表 5 治療法

\begin{tabular}{cc}
\hline \hline 治療法 & 症例数 \\
\hline $\mathrm{O}$ のみ & 15 \\
$\mathrm{O}+\mathrm{R}$ & 6 \\
$\mathrm{O}+\mathrm{C}$ & 2 \\
$\mathrm{O}+\mathrm{C}+\mathrm{R}$ & 1 \\
$\mathrm{R}$ のみ & 1 \\
$\mathrm{C}$ のみ & 0 \\
$\mathrm{R}+\mathrm{C}$ & 1 \\
$\mathrm{~L}$ のみ & 2 \\
未治療 & 1 \\
\hline 計 & 29
\end{tabular}

$\mathrm{O}:$ 手術, $\mathrm{R}$ : 放射線療法

$\mathrm{C}:$ 化学療法, $\mathrm{L}:$ レーザー焼灼

気管切開の必要を認めた. 甲状腺癌も疑っていたため, 甲状腺から距離を取って, 下方で気管切開した. 反省点 として，気管切開から手術までの期間が長かったことが 挙げられる. これは気管支鏡検査の最中に $\mathrm{SaO}_{2}$ が低下 してしまい，肺陰影の精査に期間を費やしたのが原因で ある．甲状腺癌の播種の危険も考えられたので，気管切 開を施行した後は極力短期間のらちに手術をするべき だったと考光た。

再建術の皮弁の選択については遊離皮弁子勿論, 適応 であったが，有茥皮弁でも十分可能であったと考えた。 有茎皮弁の選択に関しては，大胸筋皮弁を利用すると自 験例が肥満であったため右乳房の脂肪が邪魔になると考 光, 広背筋皮弁を用いた。

4. 病理組織学的分類 : 腺様囊胞癌は組織学的に特徵 的な篩状構造を呈する悪性腫瘍である. Osborn ${ }^{32)}$ の集 計によると 1712 例の頭頸部粘膜腺由来の腫瘍のうち, 557例 (32.5\%) が腺様囊胞癌であった. Conley ら ${ }^{33)} に よ$ ると, 小唾液腺由来の癌の中では $38 \%$ と最多を占め, 顎 下腺悪性腫瘍の $31 \%$ ，耳下腺悪性腫瘍の $14 \%$ と報告され ている. 発生部位としては口蓋, 舌, 鼻腔・副鼻腔, 口 腔が多く，喉頭や気管は比較的少ない.O Osborn ${ }^{32)}$ の集 計の557例中, 喉頭に発生したものは22例(3.9\%)であっ た. また, 喉頭の粘膜腺由来の腫瘍のうち, 腺様囊胞癌 は $32 \%$ 占める.

頭頸部以外でも肺, 乳腺, 子宮頸部, 外陰部などにも 発生し, 組織像はどの組織の腺様囊胞癌も同様の特徵所 見を呈している.

腺様囊胞癌の病理組織像は分化度の高い順に, tubu- 
表 6 Szanto の悪性度分類

$\begin{array}{ll}\text { grade } 1 & \begin{array}{l}\text { 管状, 篩状構造が主体をなし, 充実性の胞巣が } \\ \text { ないもの }\end{array} \\ \text { grade } 2 & \begin{array}{l}\text { 充実性の胞巣がみられるものの } 30 \% \text { 以下である } \\ \text { もの }\end{array} \\ \text { grade } 3 & \text { 充実性の胞巣が多くを占めるもの }\end{array}$

lar 型, cribriform 型, trabecular 型, solid 型の 4 型に 分類されている. 通常, 同一腫瘍内にこれら 4 つの組織 型がさまざまな比率で混在して和り，その中でも最も優 位を占める組織型で腫瘍を表現している.そして，分化度 の低い組織型ほど予後不良とされている. 自験例は cribriform 型であり，予後は比較的良好なことが予想される.

山本ら ${ }^{34)}$ は顕微鏡的蛍光測定法を用いて核 DNA 定量 を行い, cribriform 型, trabecular 型, solid 型の順に 増殖が方進していることより，優位な組織型別予後を推 測する有力な根拠であると報告している.

また, Szanto ら ${ }^{35)}$ の悪性度分類(表 6 )を用いた野々 村ら ${ }^{36)}$ の検討によると, 組織型と予後の関連では grade が高いほど予後不良といわれている。

5. 予後, 重複癌: 腺椂囊胞癌は緩徐に進行する傾向 があり, 予後は 5 年生存率と 10 年生存率に大きな差があ る. 進行が遅く経過が長いだけであり，必ずしも予後良 好といえず，長期に渡る撖重な経過観察が必要とされて いる34)。また，自験例のように多重癌を発症した症例は さらに他の部位にも発癌する危険性があると考兄られ， 喉頭，甲状腺，肺以外の部位も含めた全身検索を定期的 に行ら方針である. 当科に和いて喉頭癌102例中12例に 重複癌を認めたが，死亡した10例はいずれも他癌が原因 であった. 生存している 2 例は自験例と甲状腺乳頭癌と の重複癌症例の久である. 自験例の病理組織型は喉頭癌 が腺様囊胞癌の cribriform 型, 甲状腺癌が乳頭癌であ り，双方の癌の予後はともに比較的良好であると考光た， また，第一癌の乳癌は発症してからすでに15年経ってお り，再発の危険性は低いと考兵た。肺癌の病理組織型は 高分化型腺癌であった. 乳癌の病理組織型も腺癌であっ たが，肺病変は明らかに肺原発と考兄られる病理組織像 を呈していた．今後，肺は当院外科にて経過観察し，喉 頭, 甲状腺と併せて再発掞よび新たな部位での発癌に備 え，少なくとも10年以上，経過観察していきたいと考光 ている.

\section{結 語}

1）喉頭の腺様囊胞癌の 1 症例を経験した.

2 ) 喉頭癌, 甲状腺癌, 肺癌が同時性に, 乳癌が異時 性に発症した四重癌であった.

3 ) 喉頭全摘術, 下咽頭拉よび舌根の部分切除術, 甲 状腺亜全摘術, 右機能的頸部郭清術, 広背筋有茎皮弁を 用いた再建術を施行した.

4 ）腺様囊胞癌の病理組織型は cribriform 型で予後 は比較的良好であると考兵た。

5 ）腺様锤胞癌は緩徐に進行する傾向があるため, 長 期にわたる厳重な経過観察が必要と考えた。

本論文の要旨は, 日本耳鼻咽喉科学会第25回四国四県地方部 会連合学会 $(1999$ 年 6 月 6 日, 松山), 第61回耳鼻咽喉科臨床学 会(1999年 6 月25，26日，別府)飞てロ演した.

病理組織のコメントを頂戴した香川労災病院病理科の溝㴊光 一先生に深謝いたします。

\section{参考文献}

1) Donovan DT and Conley J : Adenoid cystic carcinoma of the subglottic region. Ann Otol Rhinol Laryngol 92 : $491 \sim 495,1972$.

2 ) 竹田千里 : 頭頸部腫瘍図譜. 中山書店, 東京, 1972.

3 ) 豊田弥八郎, 斉藤 等, 佐藤文彦: 頭頸部 adenoid cystic carcinoma の臨床像. 耳喉 $47: 469 \sim 474,1975$.

4 ) 佐藤武男, 古川 裕, 宮原 裕, 他: 喉頭腺癌 3 例一喉 頭に腺癌はなぜ少ないか一. 耳喉 $48 ： 279 \sim 284,1976$.

5 ）小池聰之, 小笠原利彰, 森脇昭介, 他 : 喉頭腺癌 3 例. 耳 鼻臨床 $71: 1101 \sim 1107,1978$.

6 ）星谷 勤, 兵 行和, 細井裕司, 他 : 喉頭腺様囊胞癌の 1 例. 耳鼻臨床 $71: 1189 \sim 1199,1978$.

7 ) 福島典之, 村上 譲, 平川勝洋, 他 : 喉頭腺癌の 2 症例. 耳喉 $55: 39 \sim 43,1983$.

8 ）佐藤日出夫, 飯田茂穂, 木谷正樹, 他 : 喉頭全摘を要した adenoid cystic carcinoma の切除例. 日胸外会誌 $31: 194$, 1983.

9 ) 牧 清人, 石井英男 : 20 年間治療を続けた喉頭腺様囊胞癌 の 1 例. 日耳鼻 $87: 854,1984$.

10）石津吉彦, 横山道明, 高岡基雄 : 喉頭に発生した Adenoid cystic carcinoma の 1 例. 耳鼻臨床 $78: 1852 \sim 1855,1985$.

11) 田辺正博, 松本正郎, 張田 裕: 喉頭腺様囊胞癌(声門下 癌)症例. 日気食会報 $38: 53 \sim 58,1987$.

12）伊藤孝明, 光岡明夫, 賀来克彦, 他 : 喉頭原発腺様囊胞癌 肺転移の 1 手術例. 肺がん $28: 266,1988$.

13）小山郁夫, 明海国賢, 滝口 峻: 喉頭腺様囊胞癌症例. 日 耳鼻 91 : 1490, 1988. 
14）折館伸彦, 田中克彦, 福田 諭, 他：喉頭に搞ける腺癌 腺様豊胞癌の 3 例. 耳鼻 $35: 659 \sim 663,1989$.

15）知念信雄, 原口茂徳, 野田 寛: 喉頭腺様囊胞癌の 1 症例. 日気食会報 $40: 171,1989$.

16）石毛雄幸, 木田亮紀, 古阪 徹, 他: 喉頭に発生した腺様 霊胞癌の 1 症例. 日気食会報 $40: 171,1989$.

17）吉岡康弘, 米井 潔, 米川紘子, 他 : 喉頭腺様囊胞癌. 日 耳鼻 $92: 2131,1989$.

18）中島博昭, 菊地原基敬, 岩澤 寛, 他 : 喉頭原発と思われ る adenoid cystic carcinoma の 1 例. 日気食会報 $42: 194$ $\sim 195,1991$.

19）小川佳伸, 松永 喬, 宮原 裕, 他: 喉頭の腺様囊胞癌例. 耳鼻臨床 $86: 1739 \sim 1745,1993$.

20）金田規嗣, 堀 文彦, 渡辺徳武, 他 : 喉頭腺様囊胞癌の 1 症例. 日気食会報 $44: 160,1993$.

21）矢田恒雄, 吉藤美佳, 西村俊二, 他 : 声門下腺様囊胞癌の 1 症例. 日気食会報 $44: 160,1993$.

22）松永信也, 徳島栄一郎, 河野もと子, 他 : 喉頭に発生した 腺様整胞癌の 1 症例。日気食会報 $40: 171,1989$.

23）楠山敏行, 福田宏之, 酒向 司, 他 : 喉頭腺様囊胞癌の二 例. 日気食会報 $45: 195,1994$.

24）能埜御堂浩, 塩谷彰浩, 藤井正人, 他: 喉頭 (声門下)腺様 囊胞癌の 1 例. 耳啒頭頸 $67: 333 \sim 336,1995$.

25）植田 宏, 吉田知之, 山口秀樹, 他 : 喉頭の腺系悪性腫瘍 について。 日気食会報 $49: 11 \sim 19,1998$.

26）海沼和彦, 後藤昭信, 鈴木俊哉, 他 : 声門下腺様囊胞癌の 2 症例. 耳鼻臨床 補100:119 124, 1999.

27) Ferlito A and Caruso G : Biological behavior of laryngeal adenoid cystic carcinoma ; therapeuic considerations. ORL $45: 245 \sim 256,1983$.

28）浅井昌大, 菅澤 正 : 当科における腺様囊胞癌症例の検討. 日耳鼻 95 : 346〜351, 1992.

29）持松いずみ, 佃 守, 澤木修二 : 頭頸部の腺様囊胞癌症 例の検討. 耳鼻 $29: 849 \sim 853,1983$.

30）木田あさ紀, 青柳充雄, 川村 繁, 他 : 頭頸部の腺癌及び 腺様囊胞癌の化学療法. 耳鼻 $32: 612 \sim 617,1986$.

31) Dick HL, Mulder PHM, Vermorken JB, et al : Cisplatinbased chemotherapy in advanced adenoid cystic carcinoma of the head and neck. Head Neck $14: 273 \sim 277,1992$.

32) Osborn : Tumors of the upper respiratory tract and ear. AFIP, Washington, D.C. : 90 95, 1988.

33) Conley J and Digman DL : Adenoid cystic carcinoma in the head and neck (Cylindroma). Arch Otolaryngol $100: 81 \sim 90,1974$.

34）山本祐三, 坂 哲朗, 高橋宏明 : 腺様囊胞癌の基礎と臨床. 耳鼻臨床 $84: 1153 \sim 1166,1991$.

35) Szanto PA, Luna MA, Tortoledo ME, et al : Histologic grading of adenoid cystic carcinoma of the salivary glands. Cancer $54:$ 1062 1069, 1984.

36）野々村直文, 川名正博, 大倉隆弘, 他 : 頭頸部腺様囊胞癌 症例の検討. 耳喉頭頸 $68: 306 \sim 310,1996$.

$$
\left(\begin{array}{l}
\text { 原稿受付 : 平成 } 11 \text { 年 } 9 \text { 月 } 1 \text { 日 } \\
\text { 原稿採択 : 平成11年12月 } 8 \text { 日 } \\
\text { 別刷請求先 : 村川哲也 } \\
\text { 干 } 359-8513 \text { 埼玉県所沢市並木3-2 } \\
\text { 防葦医科大学校耳鼻咽喉科学講座 }
\end{array}\right)
$$

